\title{
ANALYSIS OF HOMA-IR, FOLLICLE SIZE, AND ESTRADIOL AFTER COMBINATION THERAPY OF METFORMIN AND CLOMIPHENE CITRATE IN POLYCYSTIC OVARY SYNDROME'S PATIENT
}

\author{
Sylvy Medtasya $\mathrm{D}^{1}$, Yulistani ${ }^{2}$, Budi Santoso ${ }^{3}$ \\ ${ }^{1}$ Student Master of Clinical Pharmacy, ${ }^{2}$ Department of Clinical Pharmacy, Faculty of Pharmacy \\ ${ }^{3}$ Department of Obstetry and Gynaecology, Faculty of Medicine, Universitas Airlangga
}

\begin{abstract}
ABSTRAK
Sindroma Ovarium Polikistik (SOPK) merupakan suatu disfungsi endokrin dengan penyebab yang belum jelas diketahui, namun diperkirakan terkait dengan tingginya kadar androgen dan insulin akibat gangguan pulsasi pada gonadotropin. Tujuan penelitian ini ialah untuk menganalisis perubahan nilai HOMA-IR, ukuran folikel, dan estradiol pasca pemberian terapi kombinasi metformin dan klomifen sitrat pada pasien sindroma ovarium polikistik. Jenis penelitian ini ialah observasional longitudinal prospektif, jumlah sampel sebanyak 19 subyek dengan diagnosa akhir SOPK yang memiliki BMI $\geq 25 \mathrm{Kg} / \mathrm{m}^{2}$ dan memperoleh terapi kombinasi Metformin $500 \mathrm{mg}$ sehari tiga kali selama 10 minggu dan klomifen sitrat $100 \mathrm{mg}$ pada hari ke-3 sampai ke-7 menstruasi selama 2 siklus. Subyek penelitian diobservasi sebelum dan sesudah terapi kombinasi tersebut dengan mengukur parameter ukuran folikel, kadar glukosa dan insulin puasa untuk menghitung nilai HOMA-IR dan kadar estradiol pada minggu ke-0, minggu ke-5, dan minggu ke-10. Setelah 10 minggu dan 2 siklus menstruasi, dari 19 Subyek penelitian didapatkan perbedaan bermakna $(p<0,05)$ antara ukuran folikel, HOMA-IR, dan kadar estradiol sebelum terapi (pada minggu ke-0) dengan minggu ke-5 dan minggu ke-10. Pada minggu ke-5, subyek penelitian menunjukkan penurunan HOMA-IR dan kadar estradiol serta peningkatan ukuran folikel yang bermakna dengan nilai $p<0,05$. Setelah 10 minggu terapi kombinasi, subyek penelitian menunjukkan respon yang lebih baik lagi dengan penurunan HOMA-IR dan kadar estradiol serta peningkatan ukuran folikel yang bermakna $(p<0,05)$ dibandingkan minggu ke-5 dan minggu ke-0. Berdasarkan hasil penelitian didapatkan penurunan bermakna nilai HOMA-IR dan kadar estradiol, serta peningkatan bermakna ukuran folikel pada pasien sindroma ovarium polikistik setelah pemberian terapi kombinasi metformin selama 10 minggu dan klomifen sitrat selama 2 siklus yang diberikan bersamaan sejak awal terapi.(FMI 2015;51:162-167)
\end{abstract}

Kata kunci: Sindroma ovarium polikistik, metformin, klomifen sitrat, HOMA-IR, ukuran folikel, estradiol

\begin{abstract}
PCOS is an ovarian dysfunction syndrome which characterized by the present of unovulation, hyperandrogenism, and polycystic ovarian morphology. The main cause of PCOS is still unclear, but many studies report that genetic factor have a great role. There are also two big concept in PCOS, hyperandrogenism and insulin resistance. Previous research by Ayaz et al (2013) has shown that metformin was given if there has been a resistance of clomiphene citrate. This study was designed to provide metformin and clomiphene citrate combination from the early administration to determine the effectiveness of the combination therapy. The objective of this study is to analyze HOMA-IR value, follicle size, and estradiol concentration after metformin and clomiphene citrate treatment in PCOS patient. Design of this study was an observational longitudinal prospective method. There was only a group with a total sample size 19 women of productive age (18-40 years) diagnosed with PCOS. The pre and post combination therapy was observed for ten weeks. Metformin $500 \mathrm{mg}$ three times daily for ten weeks and clomiphene citrate $100 \mathrm{mg}$ in 3rd day until 7th day of menstruation for two cycles were given to the subjects. The result showed that HOMA-IR value decrease after 10 weeks in which value before therapy was $4.9 \pm 2.4$ and after therapy $3.7 \pm 2.2$ with the achievement $21.1 \%$ HOMA-IR under 2.5. Estradiol concentration after therapy also decreased from $64.8 \pm 24.7 \mathrm{pg} / \mathrm{ml}$ to $37.9 \pm 17.9 \mathrm{pg} / \mathrm{ml}$ in ten weeks this concentration remained the range of the follicular phase estradiol levels. On the other hand, follicle size increased from $4.7 \pm 0.6 \mathrm{~mm}$ to $10.7 \pm 2.2 \mathrm{~mm}$ after combination therapy of metformin and clomiphene citrate with the occurrence of ovulation $31.6 \%$ but none of the samples were successfully pregnant. It is concluded that women with PCOS, declined HOMA-IR, estradiol, and increased follicle size was associated with a good response to combination therapy of metformin and clomiphene citrate.(FMI 2015;51:162-167)
\end{abstract}

Keywords: polycystic ovary syndrome, metformin, clomiphene citrate, HOMA-IR, follicle size, estradiol, PCOS

Correspondence: Sylvy Medtasya Dzykryanka, Student Master of Clinical Pharmacy, Faculty of Pharmacy, Universitas Airlangga, Jl. Airlangga 6-8, Surabaya 60286. Phone: 08165417386. E-mail: ivytasya@ gmail.com

\section{INTRODUCTION}

Polycystic ovary syndrome (PCOS) is a syndrome of ovarian dysfunction with characteristic of anovulation, hyperandrogenism, and/or the presence of polycystic ovarian morphology. This syndrome is the most common endocrine disorder in women, present in approximately $5-7 \%$ of all women of reproductive age. This 
syndrome was introduced by Stein and Leventhal in 1935 based on their observations of symptoms consisting of amenorrhea, hirsutism and obesity in women whose ovaries are enlarged with follicular cysts are many and thickening fibrotic of the tunica albuginea and the cortical stroma (Falbo et al 2009).

Based on epidemiological studies, the prevalence of PCOS is likely to increase to about $4-12 \%$ of women of reproductive age (Ayaz et al 2013). Results of a survey conducted in England and New Zealand showed that the prevalence of PCOS is by $20 \%-25 \%$ of women of childbearing age (Balen 2004). In Indonesia there has been no complete national data on the prevalence of PCOS. However, based on research at several hospitals in Indonesia, women with PCOS in Indonesia was around 16\% (Biljan et al 1999).

The main cause of PCOS is not clear. However, studies by Yen et al in 1987 proposed a hypothesis based on the classic two major concepts of hyperandrogenism and insulin resistance. The imbalance of secretion of luteinizing hormone (LH) and follicle stimulating hormone (FSH) in pituitary level causes hypersecretion of endogenous LH. LH very strongly stimulates androgen production in the ovaries and then in granulosa cells the androgen will undergo aromatization to become estrogens. Insulin, as well as LH, can directly stimulate steroid hormone biosynthesis in the ovary, especially ovarian androgen. Furthermore, this insulin causes decreased production of sex hormone binding globulin (SHBG) in the liver, leading to increased levels of free androgens. Thus, these two pathways will stimulate ovarian theca cells, resulting in increased production of androgens from the ovaries which causes disruption of folliculogenesis, abnormal menstrual cycles and oligo/chronic anovulation. Lifestyle is also associated as a trigger of PCOS, especially unbalanced diet that is high-calorie diet coupled with lack of exercise (sedentary lifestyle), resulting in obesity that causes abnormalities in insulin receptor autophosphorylation (Dunaif 1997). Therefore, BMI (Body Mass Index) is a major determining factor in insulin resistance and hyperinsulinemia (Rotterdam ESHRE/ASRM 2004).

Clomiphene citrate is still the first line treatment in dealing with anovulation in PCOS patients. However, the use of clomiphene citrate is only in ovulation induction, since clomiphene citrate is as an antiestrogen, but it does not address the basic causes of the pathogenesis of PCOS, such as hyperinsulin and hyperandrogen. Clomiphene citrate occupy estrogen receptors located in the hypothalamus and pituitary. As a result of anti-estrogenic feature of clomiphene citrate, the hypothalamus and the pituitary will receive a wrong perception, as if there was reduction in estrogen levels in the peripheral circulation, thereby increasing the amplitude of FSH secretion in PCOS patients. The success rate of ovulation treatment of clomiphene citrate is $\pm 70 \%$, but the pregnancy success rate is only $30-40 \%$ (Harwood et al 2007). Although clomiphene citrate is the first line drug for ovulation induction in PCOS patients, obese women with PCOS often less respond to clomiphene citrate. This may be caused by insulin resistance and in conjunction with hyperinsulinemia.

Metformin as an insulin sensitizer is usually given to patients with PCOS due to insulin resistance, resulting in hyperinsulinemia that makes hyperandrogen affects the ovulation process. Metformin is a biguanide class of oral antidiabetic whose work is increasing insulin sensitivity in peripheral tissues so that the decrease in insulin will reduce ovarian androgen production and an increase in SHBG so that the amount of free androgens will decrease and improves menstrual cycle and ovulation. Metformin is $50 \%$ better than placebo in the induction of ovulation in PCOS patients (RR 1:50; $95 \%$ CI 1.13-1.99) and also can improve menstrual cycles compared to placebo (RR 1:45; 95\% CI 1.11-1.90) (Kashyap et al 2004). Systematic review and metaanalysis of 13 studies randomized control trial demonstrated the effectiveness of metformin in improving clinical and biochemical profiles in PCOS. The result is the effectiveness of metformin in ovulation induction compared to placebo (OR 3.88 ; 95\% CI 2.256.69) and the combination of metformin and clomiphene citrate compared to clomiphene citrate alone (OR 4.41; 95\% CI 2:37 to 8:22). The incidence of pregnancy shows significant therapeutic effect in the combination of metformin and clomiphene citrate (OR 4:40; 95\% CI 1.96-9.85) (Legro et al 2007). Ayaz et al study also showed that administration of clomiphene citrate and metformin combination can significantly regulate menstrual cycle and increases ovulation and conception in PCOS patients without complications (Lord et al 2003).

In this study, we conducted observation in patients with PCOS who were given with a combination therapy of metformin and clomiphene citrate. By administering the combination therapy since the inception, it was expected that it affect and improve body mass index and further affects the anterior pituitary to produce FSH and LH so that it can be stimulated in the ovaries and follicle development may occur which in turn may induce ovulation.

\section{MATERIALS AND METHODS}

The study was conducted from November to December 2014. This study used observational prospective long- 
itudinal design with one group pre and post, in which no treatment was done to the subjects. Observation was only carried out on to the samples that met inclusion criteria, which were women of repro-ductive age of 1840 years with BMI $\geq 25 \mathrm{~kg} / \mathrm{m}^{2}$ and was finally diagnosed with PCOS according to Rotterdam criteria that met two or more criteria (Falbo et al 2009). This study had also been approved by the ethica committee. The exclusion criteria included pregnant and lactating women, patients with a history of diabetes mellitus or uncontrolled hypertension, patients with impaired liver function (ALT > $2.5 \mathrm{ULN}$ ) and impaired renal function $(\mathrm{CrCl} \geq 1.5 \mathrm{ULN})$, patients with a history of gynecologic surgery, receiving metformin therapy, contraceptive pills, or other hormones before, or consume the drugs in the last 3 months.

During the study period we obtained 22 patients with final diagnosis of PCOS. Of the 22 patients, who met the inclusion criteria in terms of BMI $\geq 25 \mathrm{~kg} / \mathrm{m}^{2}$, there were only 20 patients, and there was one patient dropped out because the patient must undergo laparoscopy, making a total of 19 samples observed and received combination therapy of metformin $500 \mathrm{mg} 3$ times a day for 10 weeks and clomiphene citrate $100 \mathrm{mg}$ for 5 days ie on menstrual day 3 to 7 for two cycles. Subjects who did not menstruate or amenorrhea were given induction first to be able to menstruate.

Follicles were measured using transvaginal ultrasound and we found follicles in a large number and size distribution was small, between $3-8 \mathrm{~mm}$, and we examined levels of fasting blood glucose, fasting insulin levels, levels of estradiol (E2) in week 0 (before treatment), 5, and 10, and after administration of the combination therapy of metformin and clomiphene citrate. Blood taken for estradiol examination was performed on the same conditions and time during blood sampling before treatment, which was between the first to third day of menstruation. The multiplication result of fasting blood glucose and fasting insulin levels is divided by a constant (result of multiplication of basal fasting glucose and insulin level), resulting in HOMAIR value. Reduced RHOMA-IR value may occur in about 40-60\% in patients with PCOS (Yen 1986).

Data analysis used paired samples t test (paired t-test) for data with normal distribution and Wilcoxon signed rank test for not normally distributed data. Pre- and post administration of metformin and clomiphene citrate was based on the measurement results of HOMA-IR, follicle size and estradiol levels with $\mathrm{p}<0.05$, indicating statistical significance. Continuous data, such as age, BMI values etc, are described as mean and standard deviations.

\section{RESULTS}

Of 19 samples observed at week 0 (baseline), it was found that the sample's average age was $28.9 \pm 3.9$ years with the largest distribution in the age range 26-33 years, followed next with a lifespan of 18-25 years, and the lowest percentage was in the age range 18-25 years. Average BMI was $33.8 \pm 7.3 \mathrm{~kg} / \mathrm{m}^{2}$, which means an average of the samples included in the category of obesity. Mostly were subjects with obese BMI category as many as 11 patients (57.9\%) and overweight BMI of 8 patients $(42.1 \%)$. Nineteen samples also showed clinical signs of hirsutism but only 15 patients $(78.9 \%)$ had acne. Amenorrhea occurs only in 8 patients $(42.1 \%)$.

Table 1. Characteristics of the subjects in obstetric clinic, RSIA Kendangsari, from November to December, 2014

\begin{tabular}{lccc}
\hline Subject characteristics $(\mathrm{n}=19)$ & N patients & Percentage $(\%)$ & Mean \pm SD \\
\hline Age $($ years $)$ & - & - & $28.9 \pm 3.9$ \\
$18-25$ & 5 & 26.3 & - \\
$26-33$ & 10 & 52.6 & - \\
$34-40$ & 4 & 21.1 & - \\
BMI $\left(\mathrm{kg} / \mathrm{m}^{2}\right)$ & - & - & $33.8 \pm 7.3$ \\
Overweight $\left(25-29.9 \mathrm{~kg} / \mathrm{m}^{2}\right)$ & 8 & 42.1 & - \\
Obesity $\left(\geq 30 \mathrm{~kg} / \mathrm{m}^{2}\right)$ & 11 & 57.9 & - \\
Hirsutism & 19 & 100 & - \\
Acne & 15 & 78.9 & - \\
Amenorrhea & 8 & 42.1 & - \\
Length of marriage (years) & 19 & 100 & $4.2 \pm 2.4$ \\
\hline
\end{tabular}


HOMA-IR value changes between week 0 and 5 , week 0 to week 10 and between week 5 and 10 were analyzed with non-parametric Wilcoxon signed rank test and showed a HOMA-IR significantly decrease $(\mathrm{P}<0.05)$ after administration of the combination therapy of metformin $500 \mathrm{mg} 3$ times a day for 10 weeks and clomiphene citrate $100 \mathrm{mg}$ on days 3 to 7 for 2 menstrual cycles. Based on the results of the analysis of folicular size with a paired $t$ test result a significant increase follicle size between weeks 0,5 and 10 at $\mathrm{P}$ $<0.05$.

The size of follicles between week 0 and week 5 , week 0 to week 10 and between weeks 5 and 10 , which were analyzed by paired $t$ test, also showed an increase in ( $p$ $<0.05)$ after administration of the combination therapy of metformin $500 \mathrm{mg} 3$ times a day for 10 weeks and clomiphene citrate $100 \mathrm{mg}$ on days 3 to 7 for 2 menstrual cycles.

The results of estradiol analysis with paired t test results showed significant reduction in estradiol levels between week 0 and week 5 , week 0 and week 10 , week 5 and week 10 with $p<0.05$ after administration of the combination therapy of metformin $500 \mathrm{mg} 3$ times a day for 10 weeks and clomiphene citrate $100 \mathrm{mg}$ on days 3 to 7 for 2 menstrual cycles.

\section{DISCUSSION}

From 19 samples, it was found that 4 samples had HOMA-IR after 5 and 10 weeks of combination therapy of metformin and clomiphene citrate. From these four, 3 were categorized as overweight and one sample had the category of obesity. This indicates that obese condition may also experience a decrease in HOMA-IR up to $<2.5$, although the BMI did not decreased significantly. However, insulin resistance that occurs can be resolved. According to a study by Falbo et al in 2009, HOMA-IR decreased from $3.10 \pm 0.62$ to $2.61 \pm 0.39$ after administration of metformin and clomiphene citrate combination therapy for 6 cycles (Palomba et al 2006). The study suggested that combination therapy of metformin and clomiphene citrate is given in six cycles to obtain maximum results.

Table 2. Summary of statistical analysis results of the three parameters in this study

\begin{tabular}{ccccccc}
\hline Parameters & \multicolumn{3}{c}{ Mean \pm SD in week } & \multicolumn{3}{c}{$\begin{array}{c}\text { (significance) } \\
\text { in week }\end{array}$} \\
\cline { 2 - 6 } & $0-5$ & $5-10$ & $0-10$ & $0-5$ & $5-10$ & $0-10$ \\
\hline HOMA-IR & $4.9 \pm 2.4$ & $4.2 \pm 2.2$ & $3.7 \pm 2.2$ & 0.000 & 0.000 & 0.000 \\
Follicular size & $2.4 \pm 1.2$ & $3.6 \pm 1.5$ & $6.1 \pm 2.2$ & 0.000 & 0.000 & 0.000 \\
Estradiol level & $18.6 \pm 16.9$ & $8.3 \pm 6.8$ & $26.9 \pm 19.2$ & 0.000 & 0.000 & 0.000 \\
\hline
\end{tabular}

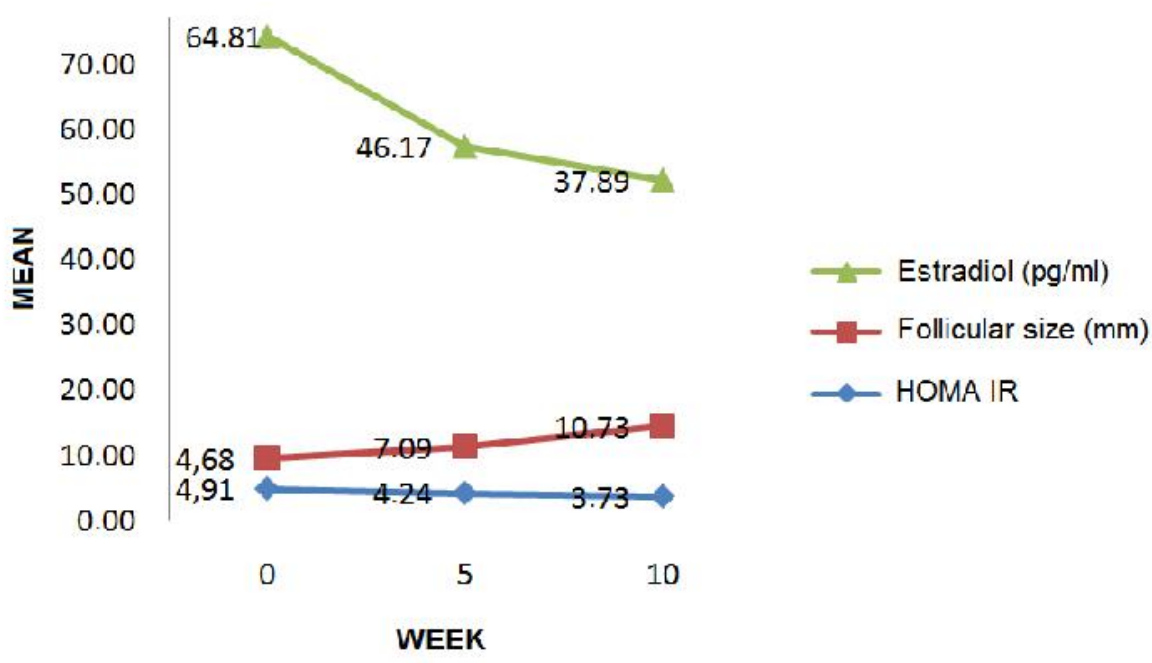

Figure 1. The curve changes in HOMA-IR values, follicle size and estradiol levels after the administration of the combination therapy of metformin and clomiphene citrate. 
A study by Moll et al in 2006 showed that ovulation can occur in $61.3 \%$ (27 of 44) samples after combination therapy of metformin and clomiphene citrate $100 \mathrm{mg}$ for 2 cycles (Moll et al 2006). The same condition was also found in this study, where the provision of clomiphene citrate $100 \mathrm{mg}$ only for 2 cycles resulted in 6 of 19 samples $(31.6 \%)$ had ovulation (follicular size reached $>20 \mathrm{~mm}$ ). This means that the success rate of ovulation may increase after administration of the combination therapy of metformin and clomiphene citrate, although it is only given in two cycles. A study by Palomba carried out in 2006 which compared the change of follicular size by administration of clomiphene citrate $150 \mathrm{mg}$ per day in PCOS patients and normal. The study found significant increase in follicle size on clomiphene citrate administration ( $\mathrm{p}<0.05)$ in PCOS group after administration of more than 3 cycles. It is also in line with the decline of conception success rate after three cycles of administration (Harwood et al 2007). Based on these studies it can be inferred that the longer the time of administration of combination therapy of metformin and clomiphene citrate, the greater the chance of ovulation occurrence.

Anti-estrogen effects of clomiphene citrate occurs primarily in the structure of the gland (gland diameter and epithelium thickness). The negative effects of clomiphene citrate has been exacerbated by the length of the half-life of this drug (Horng et al 2008). Clomiphene citrate will significantly reduce the levels of estradiol and progesterone receptors in endometrial cytosol. Endometrial estradiol receptor levels at the end of the proliferative phase was lower in the cycle of clomiphene citrate therapy. The results also showed that estradiol levels decreased significantly ( $p \quad<0.05)$ after administration of the combination therapy metformin for 10 weeks and clomiphene citrate for 2 cycles. A study by Horng et al in 2008 states that 24 out of 37 samples ovulated spontaneously after combination therapy clomiphene citrate and metformin for 12 weeks (Norman et al 2004). It is indicating that the combination therapy of metformin and clomiphene citrate may increase the likelihood of ovulation. Clomi-phene citrate, which still persist in the body, has a long halflife (a few weeks) and slow release. This will lead to the accumulation of antiestrogenic effects in ovulation triggering drug in the next cycle (Horng et al 2008).

Based on the observation of the patients' therapy outcomes achieved for \pm 10 weeks of combination therapy of metformin and clomiphene citrate, it was found that as many as 14 patients from a total of 19 study subjects patients had decreased BMI, although the decline was not statistically significant. However, observed from the data on the patients' weight, some patients fell between 1 to $6 \mathrm{~kg}$ within \pm 10 weeks.
Decrease in HOMA-IR up to $<2.5$ also occurred in 4 patients. Outcome of ovulation was experienced only by 6 patients out of 19 subjects. Ovulation is the successful enlargement follicular size to become de Graaf follicle $(\geq 20 \mathrm{~mm})$, in which the follicle will be ready to be fertilized. The success of ovulation is not accompanied by the incidence of pregnancy, because of the six ovulating not a single one had successful pregnancy within the range of \pm 10 -week period.

In this study, administration of therapy in patients with PCOS could also cause a variety of Drug Related Problem (DRP), such as the emergence of drug side effects and compliance in drug use. Potential drug side effects are nausea, vomiting, diarrhea due to the use of metformin. DRP experienced by almost all of the subjects. Another DRP identified in this study was patients' compliance in taking metformin since the side effects in the gastrointestinal tract that often occur, and so more often counseling or information, education and communication (IEC) was needed.

\section{CONCLUSION}

Significant decrease in HOMA-IR values and estradiol level, as well as a significant increase in the size of follicles are obtained in patients with polycystic ovary syndrome after administration of the combination therapy of metformin and clomiphene citrate for 10 weeks for 2 cycles simultaneously provided since the beginning of the therapy.

\section{REFERENCES}

Ayaz A, Alwan Y, Farooq MU (2013). Metforminclomiphene citrate vs. clomiphene citrate alone: Polycystic ovarian syndrome. J Hum Reprod Sci 6, $15-18$

Balen A (2004). The pathophysiology of polycystic ovary syndrome: trying to understand PCOS and its endocrinology. Best Pract Res Clin Obstet Gynaecol 18, 685-706

Biljan MM, Mahutte NG, Tulandi T, Tan SL (1999). Prospective randomized double-blind trial of the correlation between time of administration and antiestrogenic effects of clomiphene citrate on reproductive end organs. Fertil Steril 71, 633-638

Dunaif A (1997). Insulin resistance and the polycystic ovary syndrome: mechanism and implications for pathogenesis. Endocr Rev 18, 774-800

Falbo A, Orio F, Venturella R, Rania E, Materazzo C, Tolino A, Zullo F, Palomba S (2009). Does metformin affect ovarian morphology in patients with polycystic 
ovary syndrome? A retrospective cross-sectional preliminary analysis. J Ovarian Res 2, 5

Harwood K, Vuguin P, DiMartino-Nardi J (2007). Current approaches to the diagnosis and treatment of polycystic ovarian syndrome in youth. Horm Res 68 , 209-217

Horng SG, Wang TH, Wang HS (2008). Estradiol-totestosterone ratio is associated with response to metformin treatment in women with clomiphene citrate-resistant polycystic ovary syndrome (PCOS). Chang Gung Med J 31, 477-483

Kashyap S, Wells GA, Rosenwaks Z (2004). Insulinsensitizing agents as primary therapy for patients with polycystic ovarian syndrome. Hum Reprod 19, 24742483

Legro RS, Barnhart HX, Schlaff WD, Carr BR, Diamond MP, Carson SA, Steinkampf MP, Coutifaris C, McGovern PG, Cataldo NA, Gosman GG, Nestler JE, Giudice LC, Leppert PC, Myers ER; Cooperative Multicenter Reproductive Medicine Network (2007). Clomiphene, metformin, or both for infertility in the polycystic ovary syndrome. N Engl J Med 356, 551566

Lord JM, Flight IH, Norman RJ (2003). Insulinsensitising drugs (metformin, troglitazone, rosiglitazone, pioglitazone, D-chiro-inositol) for polycystic ovary syndrome. Cochrane Database Syst Rev, CD003053

Moll E, Bossuyt PM, Korevaar JC, Lambalk CB, van der Veen F (2006). Effect of clomifene citrate plus metformin and clomifene citrate plus placebo on induction of ovulation in women with newly diagnosed polycystic ovary syndrome: randomised double blind clinical trial. BMJ 332, 1485

Norman RJ, Wu R, Stankiewicz MT (2004). Polycystic ovary syndrome. MJA Pract Essen Endocrinol 180, $132-137$

Palomba S, Russo T, Orio F Jr, Falbo A, Manguso F, Sammartino A, Tolino A, Colao A, Carmina E, Zullo F (2006). Uterine effects of clomiphene citrate in women with polycystic ovary syndrome: a prospective controlled study. Hum Reprod 21, 2823-2829

Rotterdam ESHRE/ASRM-Sponsored PCOS consensus workshop group (2004). Revised 2003 consensus on diagnostic criteria and long-term health risks related to polycystic ovary syndrome (PCOS). Hum Reprod 19, 41-47

Yen SSC (1986). The human menstrual cycle. In: Yen SSC and Jaffee RB (eds). Reproductive Endocrinology: Physiology, Pathophysiology and Clinical Management. Philadelphia, Saunders (WB) Co Ltd, p 200-236 